\title{
Alicyclobacillus sendaiensis sp. nov., a novel acidophilic, slightly thermophilic species isolated from soil in Sendai, Japan \\ Correspondence \\ Tokuzo Nishino nishino@mail.cc.tohoku.ac.jp

\author{
Naoki Tsuruoka, ${ }^{1}$ Yuri Isono, ${ }^{1}$ Osamu Shida, ${ }^{2}$ Hisashi Hemmi, ${ }^{1}$ \\ Toru Nakayama ${ }^{1}$ and Tokuzo Nishino ${ }^{1}$
}

\author{
${ }^{1}$ Department of Biomolecular Engineering, Graduate School of Engineering, Tohoku University, \\ Aoba-yama 07, Sendai, Miyagi 980-8579, Japan
} \\ ${ }^{2}$ Research Laboratory, Higeta Shoyu Co. Ltd, Choshi, Chiba 288, Japan

\begin{abstract}
An acidophilic, slightly thermophilic bacterium, designated strain $\mathrm{NTAP}-1^{\top}$, that produces a thermostable extracellular acid collagenase activity with potential industrial applications was isolated from soil of Aoba-yama Park, Sendai, Japan. The temperature range for growth was $40-65^{\circ} \mathrm{C}$, with an optimum at $55^{\circ} \mathrm{C}$, and the $\mathrm{pH}$ range for growth was $2 \cdot 5-6 \cdot 5$, with an optimum at $\mathrm{pH} 5 \cdot 5$. Analysis of the $16 \mathrm{~S}$ rDNA sequence of strain NTAP- $1^{\top}$ showed that it is most closely related to strains of the genus Alicyclobacillus. Consistently, the major constituents of the cell-membrane lipid of strain NTAP-1 ${ }^{\top}$ were $\omega$-alicyclic fatty acids. However, DNA-DNA reassociation studies showed only low similarities (less than $33 \%$ ) to any type strain of Alicyclobacillus. On the basis of the phenotypic and genotypic properties, a novel species is $\left(=\mathrm{JCM} 11817^{\top}=\right.$ ATCC BAA-609 $\left.{ }^{\top}\right)$.
\end{abstract} proposed, Alicyclobacillus sendaiensis sp. nov., represented by strain NTAP-1 ${ }^{\top}$
}

Three thermoacidophilic species of the genus Bacillus, Bacillus acidocaldarius, Bacillus acidoterrestris and Bacillus cycloheptanicus, were reclassified into the genus Alicyclobacillus on the basis of the distinctive phylogenetic position of the organisms in relation to those of other Bacillus species, as well as their unique chemotaxonomic properties, in particular the occurrence of $\omega$-alicyclic fatty acids as major fatty acid constituents of their cell-membrane lipids (Wisotzkey et al., 1992). Recently, novel species of the genus Alicyclobacillus have also been proposed: Alicyclobacillus hesperidum (Albuquerque et al., 2000) and Alicyclobacillus herbarius (Goto et al., 2002).

During the course of our screening programme for thermostable 'acid collagenase' (which has potential applications in biotechnology), we isolated, from soil at Aoba-yama Park, Sendai, Miyagi, Japan, an acidophilic bacterium that produces an extracellular thermostable collagenase with an optimum $\mathrm{pH}$ for catalytic activity at 3.9 (Nakayama et al., 2000). This bacterium, strain $\mathrm{NTAP}-1^{\mathrm{T}}$, was an aerobic, endospore-forming, rod-shaped bacterium that stained Gram-negative and was tentatively assigned as a strain of the genus Bacillus. In this study, we have carried out

Published online ahead of print on 6 December 2002 as DOI 10.1099/ ijs.0.02409-0.

The DDBJ accession number for the $16 \mathrm{~S}$ rDNA sequence of strain NTAP $-1^{\top}$ is AB084128. extensive physiological, chemotaxonomic and phylogenetic analyses to show that strain NTAP $-1^{\mathrm{T}}$ represents a novel species of the genus Alicyclobacillus, which we have named Alicyclobacillus sendaiensis sp. nov.

Strain NTAP- $1^{\mathrm{T}}$ was isolated from soil using an agar medium ( $\mathrm{pH} 4 \cdot 8$ ) containing $1.5 \%$ gelatin, $0 \cdot 01 \%$ yeast extract, $\quad 0.85 \% \quad \mathrm{NaCl}, \quad 0.5 \% \quad \mathrm{KH}_{2} \mathrm{PO}_{4}$ and $0.001 \%$ $\mathrm{MgSO}_{4} \cdot 7 \mathrm{H}_{2} \mathrm{O}$ at $60-70{ }^{\circ} \mathrm{C}$ (Nakayama et al., 2000). The type strains Alicyclobacillus acidocaldarius DSM $446^{\mathrm{T}}$, Alicyclobacillus acidoterrestris DSM $3922^{\mathrm{T}}$, Alicyclobacillus cycloheptanicus DSM $4006^{\mathrm{T}}$ and A. hesperidum DSM $12489^{\mathrm{T}}$ were obtained from the Deutsche Sammlung von Mikroorganismen und Zellkulturen (DSMZ), Braunschweig, Germany. Cells of strain NTAP $-1^{\mathrm{T}}$ were stored at $-80^{\circ} \mathrm{C}$ in broth cultures supplemented with $15 \%(\mathrm{w} / \mathrm{v})$ glycerol.

Bacterial growth was monitored for up to 7 days after inoculation by measuring the turbidity $(600 \mathrm{~nm})$ of cultures in $5 \mathrm{ml}$ liquid Bacillus acidocaldarius medium (BAM; Deinhard et al., 1987) at specified pH values (see below) in $25 \mathrm{ml}$ metal-capped test tubes incubated in a water-bath incubator. For the measurement of turbidity, an uninoculated control was used as a blank. The growth temperature range of the organisms was examined at $\mathrm{pH} 4 \cdot 0$ between 23 and $75^{\circ} \mathrm{C}$ in $5{ }^{\circ} \mathrm{C}$ steps. To determine the $\mathrm{pH}$ range for growth, the organisms were grown at $55^{\circ} \mathrm{C}$ as described above except that the $\mathrm{pH}$ of the medium was adjusted to different values with $1 \cdot 0 \mathrm{M} \mathrm{H}_{2} \mathrm{SO}_{4}$; all $\mathrm{pH}$ measurements 
were performed at room temperature. The effects of $\mathrm{NaCl}$ $(0,2,3,4,5,7$ and $9 \%, w / v)$ on growth were examined at $\mathrm{pH} 5.5$ and $55^{\circ} \mathrm{C}$. Anaerobic growth was tested using incubation at $55^{\circ} \mathrm{C}$ in $10 \mathrm{ml}$ rubber-sealed screw-cap tubes

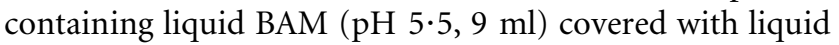
paraffin.

Cell morphology was determined using light microscopy during the exponential growth phase in BAM (pH 5.5). Sporulation was observed by using phase-contrast microscopy with cells grown to stationary phase. Gram staining was performed using exponentially growing cells according to Hucker's modification (Cowan \& Steel, 1965), with reagents produced by Nacalai Tesque. Flagellation was examined using Leifson's method (Cowan \& Steel, 1965). The following physiological tests were carried out as described previously (Albuquerque et al., 2000): catalase and oxidase reactions, the Voges-Proskauer reaction, the oxidation/fermentation test and tests for $\mathrm{H}_{2} \mathrm{~S}$ production, nitrate reduction, arginine dihydrolase, lysine decarboxylase, ornithine decarboxylase, tryptophan deaminase, $\beta$ galactosidase, gelatinase and urease. Acid production from carbon sources (see Table 2) was examined using API $50 \mathrm{CH}$ test strips (bioMérieux) and BAM $(\mathrm{pH} 4 \cdot 0)$ without glucose. Cells were resuspended in BAM without glucose at a cell density corresponding to tube no. 2 of the McFarland series of standard opacities (Cowan \& Steel, 1965). Cell suspensions $(200 \mu \mathrm{l})$ were added to API $50 \mathrm{CH}$ test-strip wells as recommended by the manufacturer and incubated at $55^{\circ} \mathrm{C}$. Acidification was observed every day for 7 days by measuring the $\mathrm{pH}$ of cultures, using a compact pH meter (model B-212; Horiba). Medium showing a pH drop of more than $0.5 \mathrm{pH}$ units, relative to a control, was regarded as positive with respect to acid production. Cultures for analysis of cellular fatty acids, isoprenoid quinones and cell-wall diamino acids were grown in 21 Erlenmeyer flasks containing $11 \mathrm{BAM}$ at pH 5.5 and $55^{\circ} \mathrm{C}$ in a reciprocal shaker until the exponential phase of growth. Analyses for cellular fatty acids, isoprenoid quinones and cell-wall diamino acids were carried out as described by Komagata \& Suzuki (1987).

Isolation and purification of chromosomal DNA and estimation of DNA base composition by HPLC were performed according to Tamaoka \& Komagata (1984). DNA reassociation values were determined as described by Ezaki et al. (1989). Briefly, probes for DNA hybridization were prepared from cells of $A$. acidocaldarius DSM $446^{\mathrm{T}}, A$. acidoterrestris DSM $3922^{\mathrm{T}}$, A. cycloheptanicus DSM $4006^{\mathrm{T}}$ and A. hesperidum DSM $12489^{\mathrm{T}}$. Probe DNAs were biotinylated with photobiotin and hybridized with singlestranded unlabelled chromosomal DNA fragments of strain NTAP- $1^{\mathrm{T}}$. Hybridized DNA fragments were visualized using alkaline phosphatase colour-detection methods (Ezaki et al., 1989). 16S rDNA was amplified by a PCR (Weisburg et al., 1991) with the universal bacterial primers 10F (5'-AGTTTGSTCCTGGCTC-3') and 1500R (5'-GGCTACCTTGTTACGA-3'). PCR products were purified with

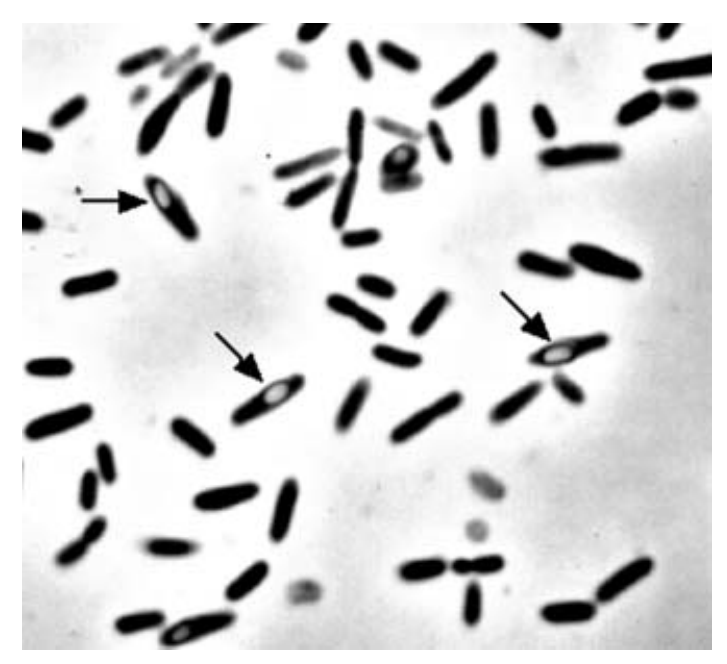

Fig. 1. Phase-contrast micrograph of sporulating cells of Alicyclobacillus sendaiensis sp. nov. Cells were cultured on liquid BAM for 3 days at $55^{\circ} \mathrm{C}$.

MicroSpin columns S-400 HR (Amersham Biosciences) and sequenced using a CEQ2000XL DNA Analysis system (Beckman Coulter). Previously published 16S rDNA sequences were obtained from the GenBank/EMBL/DDBJ databases (see Fig. 2). Multiple alignment of sequences, calculation of nucleotide substitution rates ( $K_{\text {nuc }}$ values; Kimura, 1980), construction of a neighbour-joining phylogenetic tree (Saitou \& Nei, 1987) and bootstrap analysis with 1000 replicates for the evaluation of phylogenetic tree topology (Felsenstein, 1985) were carried out using CLUSTAL W version 1.81 .

Cells of strain NTAP $-1^{\mathrm{T}}$ are rod-shaped, $2-3 \mu \mathrm{m}$ long and $0 \cdot 8 \mu \mathrm{m}$ in diameter. Cells stained Gram-negative and were non-motile. Ellipsoid endospores were produced (Fig. 1). Colonies of strain NTAP- $1^{\mathrm{T}}$ formed on BAM were circular,

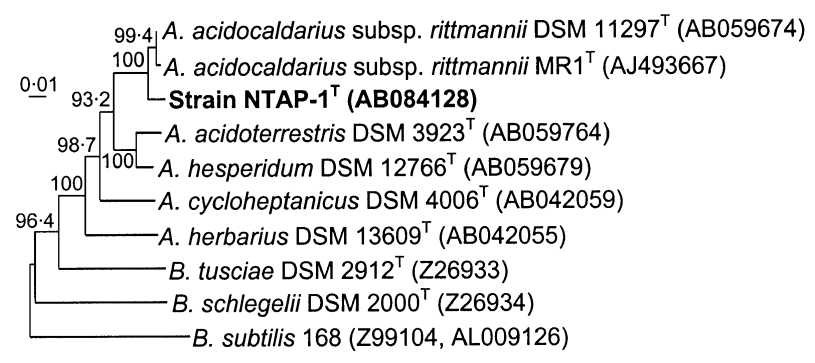

Fig. 2. Phylogenetic relationships of Alicyclobacillus species and some aerobic, rod-shaped, endospore-forming bacteria, based on 16 rRNA gene sequences. GenBank/EMBL/DDBJ accession numbers are shown in parentheses. The branching pattern was generated by the neighbour-joining method. Numbers indicate bootstrap percentages greater than $90 \%$. Bar, 0.01 nucleotide substitution per site. 
convex, white and semi-transparent, $1 \mathrm{~mm}$ in diameter after $30 \mathrm{~h}$ growth at $55^{\circ} \mathrm{C}$.

A 1438-nt stretch of the $16 \mathrm{~S}$ rDNA sequence, representing $93 \%$ of the Escherichia coli $16 \mathrm{~S}$ rDNA sequence, was determined and compared with available 16S rDNA sequences to construct a phylogenetic tree (Fig. 2). The results clearly showed that strain NTAP $-1^{\mathrm{T}}$ falls within the radiation of the genus Alicyclobacillus. Similarity values between the $16 \mathrm{~S}$ rDNA sequence of strain NTAP- $1^{\mathrm{T}}$ and those of A. acidoterrestris DSM $3923^{\mathrm{T}}$, A. acidocaldarius DSM $11297^{\mathrm{T}}$, A. hesperidum DSM $12766^{\mathrm{T}}$, A. cycloheptanicus DSM $4006^{\mathrm{T}}$, A. herbarius DSM $13609^{\mathrm{T}}$ and Bacillus tusciae DSM $2912^{\mathrm{T}}$ were respectively $98 \cdot 2,97 \cdot 9,95 \cdot 1,93 \cdot 5,92 \cdot 4$ and $89 \cdot 2 \%$. The $\mathrm{G}+\mathrm{C}$ content of strain NTAP- $1^{\mathrm{T}}$ was determined, by HPLC, to be $62.3 \mathrm{~mol} \%$, which is higher than the values determined in this laboratory for $A$. acidoterrestris DSM $3922^{\mathrm{T}}$ (51.5 mol\%), A. cycloheptanicus DSM $4006^{\mathrm{T}}$ $(57 \cdot 9 \mathrm{~mol} \%)$ and A. acidocaldarius DSM $446^{\mathrm{T}}(60 \cdot 8 \mathrm{~mol} \%)$. DNA-DNA reassociation studies of strain NTAP- $1^{\mathrm{T}}$ were performed using type strains whose $16 \mathrm{~S}$ rDNA sequences showed more than $95 \%$ similarity to that of strain NTAP- $1^{\mathrm{T}}$. Strain NTAP- ${ }^{\mathrm{T}}$ showed 33, 26 and $5 \%$ DNA-DNA reassociation, respectively, with $A$. acidocaldarius DSM $446^{\mathrm{T}}$, A. hesperidum DSM $12489^{\mathrm{T}}$ and A. acidoterrestris DSM $3922^{\mathrm{T}}$. These values are significantly lower than the threshold value $(70 \%)$ recommended for the delineation of a novel species. Thus, strain NTAP- $1^{\mathrm{T}}$ can be distinguished from representatives of all described species of Alicyclobacillus.

Table 1. Cellular fatty acid composition of strain NTAP-1 ${ }^{\top}$ and Alicyclobacillus strains

Strains: 1, NTAP- $1^{\mathrm{T}}$; 2, A. acidocaldarius ATCC $27009^{\mathrm{T}} ; 3$, A. acidoterrestris DSM $3923^{\mathrm{T}}$; 4, A. cycloheptanicus DAM $4006^{\mathrm{T}}$; 5 , A. herbarius DSM $13609^{\mathrm{T}}$ (data in columns $2-5$ from Goto et al., 2002); 6, A. hesperidum DSM $12489^{\mathrm{T}}$ (data from Albuquerque et al., 2000). Values are percentages of total fatty acids. TR, Trace.

\begin{tabular}{|lrcccccc|}
\hline Fatty acid & $\mathbf{1}$ & $\mathbf{2}$ & $\mathbf{3}$ & $\mathbf{4}$ & $\mathbf{5}$ & $\mathbf{6}$ \\
\hline $14: 0$ & & & & $0 \cdot 8$ & $0 \cdot 4$ & \\
$15: 0$ & $0 \cdot 2$ & & & $0 \cdot 6$ & $\mathrm{TR}$ & \\
$15: 0$ iso & $1 \cdot 1$ & $1 \cdot 4$ & $\mathrm{TR}$ & $0 \cdot 5$ & $0 \cdot 4$ & $5 \cdot 4$ \\
$15: 0$ anteiso & $1 \cdot 5$ & & $\mathrm{TR}$ & $\mathrm{TR}$ & $\mathrm{TR}$ & $6 \cdot 6$ \\
$16: 0$ & $4 \cdot 9$ & & $2 \cdot 5$ & $2 \cdot 4$ & $5 \cdot 1$ & $2 \cdot 1$ \\
$16: 0$ iso & $1 \cdot 6$ & $1 \cdot 4$ & & $1 \cdot 0$ & $3 \cdot 8$ & $0 \cdot 9$ \\
$17: 0$ & $0 \cdot 6$ & & & & $0 \cdot 5$ & \\
$17: 0$ iso & $4 \cdot 5$ & $1 \cdot 9$ & $1 \cdot 2$ & $2 \cdot 7$ & $5 \cdot 6$ & $4 \cdot 9$ \\
$17: 0$ anteiso & $10 \cdot 5$ & $2 \cdot 3$ & $4 \cdot 2$ & $1 \cdot 3$ & $3 \cdot 0$ & $10 \cdot 3$ \\
$18: 0$ & $0 \cdot 9$ & & & $1 \cdot 3$ & $2 \cdot 4$ & \\
$18: 0$ iso & & & & & $3 \cdot 2$ & \\
$\omega$-Cyclohexane $\mathrm{C}_{17: 0}$ & $44 \cdot 1$ & $78 \cdot 0$ & $67 \cdot 4$ & & & $56 \cdot 8$ \\
$\omega$-Cyclohexane $\mathrm{C}_{19: 0}$ & $30 \cdot 2$ & $16 \cdot 0$ & $24 \cdot 6$ & & & $13 \cdot 3$ \\
$\omega$-Cycloheptane $\mathrm{C}_{18: 0}$ & & & & $86 \cdot 8$ & $67 \cdot 1$ & \\
$\omega$-Cycloheptane $(2-\mathrm{OH})$ & $\mathrm{C}_{18: 0}$ & & & & $2 \cdot 3$ & $3 \cdot 5$ & \\
$\omega$-Cycloheptane $\mathrm{C}_{20: 0}$ & & & & $\mathrm{TR}$ & $4 \cdot 5$ & \\
& & & & & & \\
\hline
\end{tabular}

The fatty acid composition of strain NTAP- $1^{\mathrm{T}}$ is shown in Table 1. $\omega$-Alicyclic fatty acids were the major cellular fatty acids, as is the case for strains of the genus Alicyclobacillus. Examination of the respiratory lipoquinone content of strain NTAP $-1^{\mathrm{T}}$ showed that menaquinones were the only respiratory lipoquinones detected, menaquinone-7 being the predominant type. Strain NTAP $-1^{\mathrm{T}}$ contained mesodiaminopimelic acid as the wall diamino acid.

Strain NTAP $-1^{\mathrm{T}}$ was able to grow in BAM at $\mathrm{pH} 2 \cdot 5-6 \cdot 5$

Table 2. Phenotypic characteristics that differentiate species of the genus Alicyclobacillus

Strains: 1 , NTAP- ${ }^{\mathrm{T}} ; 2$, A. acidocaldarius DSM $446^{\mathrm{T}} ; 3$, A. acidoterrestris DSM $3922^{\mathrm{T}}$; 4, A. hesperidum DSM $12489^{\mathrm{T}} ; 5$, A. cycloheptanicus DSM $4006^{\mathrm{T}}$ (data in columns $1-5$ from this study); 6, A. herbarius DSM $13609^{\mathrm{T}}$ (data from Goto et al., 2002). +, Positive; W, weakly positive; - , negative; NR, not reported. All strains were positive for acid production from D-ribose, D-xylose, D-glucose, D-fructose, D-mannose and mannitol. All were negative for acid production from L-xylose, adonitol, methyl $\beta$-xyloside, L-sorbose, dulcitol, $N$-acetyl-D-glucosamine, inulin, D-lyxose, D-tagatose, L-fucose, L-arabitol, gluconate and 2-ketogluconate.

\begin{tabular}{|c|c|c|c|c|c|c|}
\hline Characteristic & 1 & 2 & 3 & 4 & 5 & 6 \\
\hline Voges-Proskauer reaction & + & - & - & - & NR & - \\
\hline Catalase activity & - & $\mathrm{w}$ & $\mathrm{W}$ & - & + & + \\
\hline \multicolumn{7}{|l|}{ Acid production from: } \\
\hline Glycerol & + & + & + & - & + & + \\
\hline Erythritol & - & - & + & - & - & - \\
\hline D-Arabinose & - & - & - & - & - & + \\
\hline L-Arabinose & + & + & + & + & - & + \\
\hline D-Galactose & + & + & + & + & - & + \\
\hline Rhamnose & - & + & + & - & + & + \\
\hline Inositol & - & - & + & - & + & - \\
\hline D-Sorbitol & - & - & + & - & - & - \\
\hline Methyl $\alpha$-D-mannoside & - & - & - & - & - & + \\
\hline Methyl $\alpha$-D-glucoside & + & - & - & - & - & + \\
\hline Amygdalin & - & - & - & - & - & + \\
\hline Arbutin & + & - & + & - & - & + \\
\hline Aesculin & - & - & - & - & - & + \\
\hline Salicin & + & - & + & + & - & + \\
\hline Cellobiose & + & + & + & + & - & + \\
\hline Maltose & + & + & + & + & - & + \\
\hline Lactose & + & + & + & - & - & + \\
\hline Melibiose & - & + & - & - & - & + \\
\hline Sucrose & + & + & - & + & - & + \\
\hline Trehalose & + & + & - & + & - & + \\
\hline Melezitose & - & - & - & - & - & + \\
\hline D-Raffinose & + & + & - & - & - & + \\
\hline Glycogen & + & - & - & + & - & - \\
\hline Xylitol & - & - & + & - & + & - \\
\hline Gentiobiose & - & - & + & - & + & + \\
\hline D-Turanose & + & + & - & - & - & + \\
\hline D-Arabitol & - & - & + & - & - & - \\
\hline D-Fucose & - & - & - & - & - & + \\
\hline 5-Ketogluconate & - & - & - & - & + & + \\
\hline
\end{tabular}


(at $55^{\circ} \mathrm{C}$ ) or at $40-65^{\circ} \mathrm{C}$ (at $\mathrm{pH} 4 \cdot 0$ ). The optimum $\mathrm{pH}$ and temperature values for growth were $\mathrm{pH} 5.5$ and $55^{\circ} \mathrm{C}$. Anaerobic growth did not occur. The organism grew in the presence of $4 \%(\mathrm{w} / \mathrm{v}) \mathrm{NaCl}$; however, no growth was observed at $\mathrm{NaCl}$ concentrations of $5 \%$ or higher. NTAP- $1^{\mathrm{T}}$ was positive for the Voges-Proskauer reaction, nitrate reduction and gelatinase activity, but negative for the oxidation/ fermentation test and tests for $\mathrm{H}_{2} \mathrm{~S}$ production, catalase, oxidase, arginine dihydrolase, lysine decarboxylase, ornithine decarboxylase, tryptophan deaminase, $\beta$-galactosidase and urease. Acid production from various carbon sources is summarized in Table 2. This acid-production pattern also distinguishes strain NTAP $-1^{\mathrm{T}}$ from known species of Alicyclobacillus.

\section{Description of Alicyclobacillus sendaiensis sp. nov.}

Alicyclobacillus sendaiensis (sen.dai.en'sis. N.L. masc. adj. sendaiensis of Sendai, a city in Miyagi Prefecture, Japan, where the type strain was isolated).

Rod-shaped, endospore-forming, strictly aerobic organism. Cells stain Gram-negative. Round spores lie terminally in swollen sporangia. The rods measure $2-3 \times 0 \cdot 8 \mu \mathrm{m}$. Cell wall contains meso-diaminopimelic acid. The predominant isoprenoid quinone is menaquinone-7. Major fatty acid components are $\omega$-alicyclic acids (of the $\omega$-cyclohexyl type). The temperature range for growth is $40-65^{\circ} \mathrm{C}$ (optimum $55^{\circ} \mathrm{C}$ ). The $\mathrm{pH}$ range for growth is $2 \cdot 5-6 \cdot 5$ (optimum $\mathrm{pH} 5 \cdot 5)$. Grows in the presence of $4 \%(\mathrm{w} / \mathrm{v}) \mathrm{NaCl}$ in BAM. Positive in the Voges-Proskauer reaction and the nitratereduction test, but negative in the oxidation/fermentation test and for $\mathrm{H}_{2} \mathrm{~S}$ production, catalase, oxidase, arginine dihydrolase, lysine decarboxylase, ornithine decarboxylase, tryptophan deaminase, $\beta$-galactosidase and urease. The pattern of acid production is shown in Table 2. The G+C content of the DNA of the type strain is $62.3 \mathrm{~mol} \%$.

The type strain, strain NTAP $-1^{\mathrm{T}}\left(=\mathrm{JCM} 11817^{\mathrm{T}}=\right.$ ATCC BAA $\left.-609^{\mathrm{T}}\right)$, was isolated from soil of Aoba-yama Park, Sendai, Japan.

\section{Acknowledgements}

We thank Professor Milton S. da Costa, Departamento de Bioquímica, Universidade de Coimbra, Portugal, for his invaluable comments and help with improving this paper. This work was supported in part by the industrial technology research grant program in 2001 from the New Energy and Industrial Technology Development Organization (NEDO) of Japan (to H. H.).

\section{References}

Albuquerque, L., Rainey, F. A., Chung, A. P., Sunna, A., Nobre, M. F., Grote, R., Antranikian, G. \& da Costa, M. S. (2000). Alicyclobacillus hesperidum sp. nov. and a related genomic species from solfataric soils of São Miguel in the Azores. Int J Syst Evol Microbiol 50, 451-457.

Cowan, S. T. \& Steel, K. J. (1965). Manual for the Identification of Medical Bacteria. Cambridge: Cambridge University Press.

Deinhard, G., Saar, J., Krischke, W. \& Poralla, K. (1987). Bacillus cycloheptanicus sp. nov., a new thermoacidophile containing $\omega$-cycloheptane fatty acids. Syst Appl Microbiol 10, 68-73.

Ezaki, T., Hashimoto, Y. \& Yabuuchi, E. (1989). Fluorometric deoxyribonucleic acid-deoxyribonucleic acid hybridization in microdilution wells as an alternative to membrane filter hybridization in which radioisotopes are used to determine genetic relatedness among bacterial strains. Int J Syst Bacteriol 39, 224-229.

Felsenstein, J. (1985). Confidence limits on phylogenies: an approach using the bootstrap. Evolution 39, 783-791.

Goto, K., Matsubara, H., Mochida, K., Matsumura, T., Hara, Y., Niwa, M. \& Yamasato, K. (2002). Alicyclobacillus herbarius sp. nov., a novel bacterium containing $\omega$-cycloheptane fatty acids, isolated from herbal tea. Int J Syst Evol Microbiol 52, 109-113.

Kimura, M. (1980). A simple method for estimating evolutionary rates of base substitutions through comparative studies of nucleotide sequences. J Mol Evol 16, 111-120.

Komagata, K. \& Suzuki, K. (1987). Lipid and cell-wall analysis in bacterial systematics. Methods Microbiol 19, 161-207.

Nakayama, T., Tsuruoka, N., Akai, M. \& Nishino, T. (2000). Thermostable collagenolytic activity of a novel thermophilic isolate, Bacillus sp. strain NTAP-1. J Biosci Bioeng 89, 612-614.

Saitou, N. \& Nei, M. (1987). The neighbor-joining method: a new method for reconstructing phylogenetic trees. Mol Biol Evol 4, 406-425.

Tamaoka, J. \& Komagata, K. (1984). Determination of DNA base composition by reversed-phase high-performance liquid chromatography. FEMS Microbiol Lett 25, 125-128.

Weisburg, W. G., Barns, S. M., Pelletier, D. A. \& Lane, D. J. (1991). $16 \mathrm{~S}$ ribosomal DNA amplification for phylogenetic study. J Bacteriol 173, 697-703.

Wisotzkey, J. D., Jurtshuk, P., Jr, Fox, G. E., Deinhard, G. \& Poralla, K. (1992). Comparative sequence analyses on the 16S rRNA (rDNA) of Bacillus acidocaldarius, Bacillus acidoterrestris, and Bacillus cycloheptanicus and proposal for creation of a new genus, Alicyclobacillus gen. nov. Int J Syst Bacteriol 42, 263-269. 